\title{
Cranial sexual discrimination in hatchling broad-snouted caiman (Caiman latirostris)
}

\author{
Carlos Piña ${ }^{1,2,3}$, Alejandro Larriera ${ }^{1}$, Pablo Siroski ${ }^{1,4} \&$ Luciano M. Verdade ${ }^{2}$ \\ 1. Proyecto YACARÉ, Tucumán 3285, (3000) Santa Fe, Argentina. (yacare@arnet.com.ar) \\ 2. Laboratório de Ecologia Animal / LEA / ESALQ, Universidade de São Paulo, Caixa Postal 09, 13418-900 Piracicaba, SP, Brazil. \\ (lmv@esalq.usp.br) \\ 3. CICyTTP-CONICET, Dr. Matteri y España, CP 3105, Diamante, Entre Rios, Argentina. (cidcarlos@infoaire.com.ar) \\ 4. Facultad de Humanidades y Ciencias, Universidad Nacional del Litoral, Argentina.
}

\begin{abstract}
Broad-snouted caiman (Caiman latirostris) hatchlings present a consistent sexual dimorphism in their cranium shape and size. Male hatchlings have smaller crania than females. Using multivariate statistical analyses it is possible to discriminate sex in broadsnouted caiman hatchlings by their cranial shape with a reasonable efficiency. The understanding of sexual dimorphism of crocodilian hatchlings might be possibly improved by experimental approach considering, genetic and phenotypic variables such as incubation
\end{abstract} temperature and clutch of origin.

KEYWORDS. Caiman latirostris, crocodilians, hatchlings, morphometrics, sexual dimorphism.

RESUMEN. Discriminación de sexo en neonatos de yacaré overo (Caiman latirostris). Los neonatos de yacaré overo (Caiman latirostris) presentan un dimorfismo sexual en la forma y tamaño de su cráneo. Los neonatos machos tienen cráneos más pequeños que las hembras. Mediante el uso de análisis estadísticos multivariados es posible discriminar el sexo de los neonatos de yacaré overo en función de su forma y tamaño con una razonable eficiencia. La comprensión del dimorfismo sexual de los neonatos de crocodilianos podría ser mejorada mediante un abordaje experimental de variables genéticas y fenotípicas, tales como la temperatura de incubación y el nido de origen.

PALABRAS-CLAVE. Caiman latirostris, crocodilianos, neonatos, morfometría, dimorfismo sexual.

Incubation temperature during embryonic development affects reptile hatchlings phenotypes, such as sex in those with temperature-dependent sex determination, body size, pigmentation, morphology, locomotory performance, growth, thermal preference, and survivorship (LANG, 1987; BURGER, 1991; LANG \& ANDrews, 1994; JANZEN, 1995; Shine \& Harlow, 1996; Rhen \& LANG, 1999; PIÑa et al., 2003). Some reptiles are sexually dimorphic in overall size (Fiтch, 1981; SмITH et al., 1997; ANDREWs et al., 2000) or in relative size of certain body structures (Doughty \& Shine, 1995; Verdade, 2001).

The evolution of sexual dimorphism can result from sexual selection and/or intraespecific niche divergence (Hedrick \& Temeles, 1989; Shine, 1989). In addition, a phylogenetically conservative trait can be maintained in species with a common ancestor (GRIFFITH, 1991), although body size is generally subjected to selection pressures (ANDERSON \& VITT, 1990).

Young and adult crocodilians (from 40 to $120 \mathrm{~cm}$ snout-vent length) have sexually dimorphic heads (WEBB \& Messel, 1978; Hall \& Portier, 1994; Verdade, 2003), but there is no available data for hatchlings. Although adult crocodilians are easily sexed by direct inspection of the cloaca (CHABRECK, 1963; BRAZAITIS, 1969), the sex of hatchlings is difficult to determine because cloacal examination usually leads to a high rate of misclassification, up to $90 \%$ (JOANEN \& MCNEASE, 1978). If multivariate analyses of hatchlings sex discrimination became as effective as they are for adult crocodilians (VERDADE, 2003) they might replace the currently available techniques: surgical examination of the gonads
(Magnusson et al., 1990) which is an invasive method; delaying sexing until animals are big enough which is time consuming; or, sacrificing animals for necropsy which is not recommended for endangered species.

In the present study, we aimed to answer the following questions concerning sexual dimorphism of broad-snouted caiman hatchlings, Caiman latirostris (Daudin, 1802): 1) does the species present cranial sexual dimorphism in hatchlings?; 2) can we efficiently discriminate gender in hatchlings based on their cranial morphometrics?; 3) what cranial measurements are more relevant for this purpose?

\section{MATERIAL AND METHODS}

We have experimentally incubated 125 eggs of Caiman latirostris from five clutches collected in the wild in Santa Fe Province, Argentina (31 ${ }^{\circ} 42^{\prime}$ 'S ; 60 $44^{\circ} \mathrm{W}$ ), during the first two days after oviposition in the Summer of 1999/2000. Temperatures of incubation and sex of hatchlings are presented in Table I. Clutches were split into different incubation treatments. We used this procedure to water down the clutch effects.

Up to 24 hours after hatching, we took 10 cranial measurements to the nearest $0.01 \mathrm{~mm}$ (Fig. 1) in 98 caimans with a Vernier caliper. Measurements were adapted from HALl \& Portier (1994), IORdANSKy (1973), and Verdade (2003). They were based on linear distances between landmarks. HALL \& PORTIER (1994) also used ratios between measurements but the use of ratios has several disadvantages. Ratios tend to be relatively inaccurate, 
not-normally distributed, and discontinuous (SOKAL \& RoHLF, 1995). For these reasons, ratios were not used in the present study.

The animals were sexed by direct observation of the gonads after completing one year of age (ALLSTEADT \& LANG, 1995; PIÑA et al., 2003). We ran single Analysis of Variance (ANOVA) for each variable and Multivariate Analysis of Variance (MANOVA) for the whole set taking sex as factor and cranial measurements as response.

We then run a discriminant analysis with crossvalidation for the variables where we found differences between sexes (four), and with a best subset of variables based on F, p-values of single ANOVA (considering Bonferroni correction), and scale (three). This way we reduced the number of measurements in order to reduce handling time and stress to the animals. Cross-validation is used to compensate for an optimistic apparent error rate. The apparent error rate is the percent of misclassified observations. This number tends to be optimistic because the classified data are the same data used to build the classification function. The cross-validation routine works by omitting each observation one at a time, recalculating the classification function using the remaining data, and then classifying the omitted observation (MINITAB, 2000).

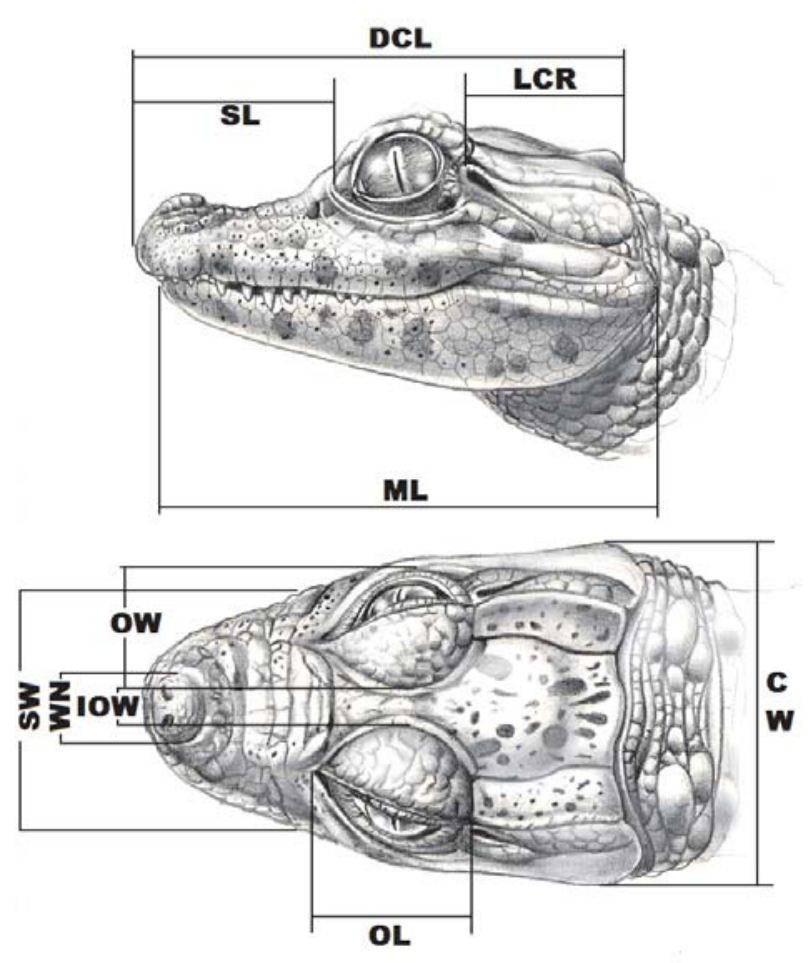

Fig. 1. Morphometric variables. Dorsal and lateral views of Caiman latirostris hatchling head (CW, cranial width, distance between the lateral surfaces of the mandibular condyles of the quadrates; DCL, dorsal cranial length, anterior tip of snout to posterior surface of occipital condyle; IOW, minimal interorbital width; LCR, length of the postorbital cranial roof, distance from the posterior orbital border to the posterolateral margin of the squamosal; ML, maximal mandibular length; OL, maximal orbital length; OW, maximal orbital width; SL, snout length, anterior tip of snout to anterior orbital border, measured diagonally; SW, basal snout width, width across anterior orbital borders; WN, maximal width of external nares).
Although clutch-effects are usually relevant for crocodilians (GARNET \& MurRaY, 1986), they could not be evaluated in the present study because clutches were not equally distributed among the distinct incubation treatments (Tab. I). All statistical analyses were run in Minitab for Windows (Minitab, 2000) and InfoStat for Windows (INFOSTAT, 1998).

\section{RESULTS}

There was sexual dimorphism in hatchling cranial morphometrics (MANOVA - Wilks' criterion: $F=8.710$, df $=87, \mathrm{P}<0.001$; Tab. II; Fig. 2). Sex was correctly assessed in $65.3 \%$ of the specimens by a Quadratic Discriminant Function (QDF) of the cranial measurements using the four following significant measurements (ANOVA: P < 0.005 for Bonferroni correction): cranial width $(\mathrm{CW})$, maximal orbital length (OL), maximal width of external nares (WN), and maximal mandibular length (ML). However, a best subset of three measurements (Dorsal cranial length (DCL), CW, and ML) slightly improved the model (QDF: $71.4 \%$ ). Misclassification occurred more often for males than on females for the whole set of significant measurements $\left(\chi^{2}=15.5, \mathrm{df}=1, \mathrm{P}<0.001\right)$ as well as for the best subset of measurements $\left(\chi^{2}=15.2, \mathrm{df}\right.$ $=1, \mathrm{P}<0.001$ ).

Table I. Sex and sample size at different incubation treatments. Shifting temperatures were 29 to $33^{\circ} \mathrm{C}$ and vice-versa (precision of incubation temperature was $\pm 0.5^{\circ} \mathrm{C}$ ). Letters (A to E) mean different nests.

\begin{tabular}{|c|c|c|c|}
\hline Incubation Treatment & $\begin{array}{c}\text { Nest } \\
\text { (\# of hatchlings } \\
\text { per nest) }\end{array}$ & Sex & $\begin{array}{l}\text { Sample Size } \\
\text { (\# of } \\
\text { hatchlings) }\end{array}$ \\
\hline $29^{\circ} \mathrm{C}$ : day 1 to hatching & B (2) D (5) & Female & 7 \\
\hline $31^{\circ} \mathrm{C}$ : day 1 to hatching & D (6) E (3) & Female & 9 \\
\hline $33^{\circ} \mathrm{C}$ : day 1 to hatching & $\mathrm{B}(1) \mathrm{C}(6) \mathrm{D}(9) \mathrm{E}(5)$ & Male & 21 \\
\hline $29^{\circ} \mathrm{C}$ : days 1 to 10 & A & Male & 4 \\
\hline $33^{\circ} \mathrm{C}$ : days 1 to 10 & A & Female & 5 \\
\hline $29^{\circ} \mathrm{C}$ : days 1 to 18 & A & Male & 4 \\
\hline $33^{\circ} \mathrm{C}$ : days 1 to 18 & A & Female & 4 \\
\hline $29^{\circ} \mathrm{C}$ : days 1 to 25 & A & Female & 3 \\
\hline $33^{\circ} \mathrm{C}$ : days 1 to 25 & A & Female & 4 \\
\hline $29^{\circ} \mathrm{C}$ : days 1 to 39 & B & Female & 1 \\
\hline $33^{\circ} \mathrm{C}$ : days 1 to 39 & B & Male & 3 \\
\hline $29^{\circ} \mathrm{C}$ : days 1 to 46 & B & Female & 2 \\
\hline $33^{\circ} \mathrm{C}$ : days 1 to 46 & $\mathrm{~B}$ & Male & 1 \\
\hline $29^{\circ} \mathrm{C}$ : days 1 to 53 & $\mathrm{C}$ & Female & 1 \\
\hline $33^{\circ} \mathrm{C}$ : days 1 to 53 & B & Male & 2 \\
\hline $29^{\circ} \mathrm{C}$ : days 1 to 60 & $\mathrm{C}$ & Female & 5 \\
\hline $33^{\circ} \mathrm{C}$ : days 1 to 60 & $\mathrm{C}$ & Male & 4 \\
\hline $29^{\circ} \mathrm{C}$ : days 1 to 67 & $\mathrm{C}$ & Female & 5 \\
\hline $33^{\circ} \mathrm{C}$ : days 1 to 67 & $\mathrm{C}$ & Male & 2 \\
\hline $29^{\circ} \mathrm{C}$ : days 1 to 74 & $\mathrm{C}$ & Female & 5 \\
\hline $33^{\circ} \mathrm{C}$ : days 1 to 74 & $\mathrm{C}$ & Male & 1 \\
\hline $29^{\circ} \mathrm{C}$ : days 1 to 81 & $\mathrm{C}$ & Female & 4 \\
\hline \multirow[t]{2}{*}{$29^{\circ} \mathrm{C}$ : days 1 to 90} & $\mathrm{C}$ & Female & 1 \\
\hline & & $\Sigma$ & 98 \\
\hline
\end{tabular}


Table II. Means \pm Standard Deviations $(\mathrm{mm})$ for all ten measurements used in the experiment, F, df, and P values from One Way ANOVAs for each variable grouped by sex, $(\mathrm{CW}$, cranial width, distance between the lateral surfaces of the mandibular condyles of the quadrates; DCL, dorsal cranial length, anterior tip of snout to posterior surface of occipital condyle; IOW, minimal interorbital width; LCR, length of the postorbital cranial roof, distance from the posterior orbital border to the posterolateral margin of the squamosal; ML, maximal mandibular length; OL, maximal orbital length; OW, maximal orbital width; SL, snout length, anterior tip of snout to anterior orbital border, measured diagonally; SW, basal snout width, width across anterior orbital borders; WN, maximal width of external nares).

\begin{tabular}{|c|c|c|c|c|c|c|}
\hline Variable & Female & Male & $\mathrm{F}$ & df & $\mathrm{P}$ & Subset \\
\hline DCL & $3.35 \pm 0.08$ & $3.31 \pm 0.12$ & 5.78 & 102 & 0.018 & YES \\
\hline $\mathrm{CW}$ & $2.18 \pm 0.08$ & $2.11 \pm 0.09$ & 18.44 & 102 & $<0.001$ & YES \\
\hline SL & $1.18 \pm 0.06$ & $1.16 \pm 0.06$ & 1.68 & 102 & 0.198 & NO \\
\hline SW & $1.46 \pm 0.06$ & $1.47 \pm 0.06$ & 1.11 & 102 & 0.294 & NO \\
\hline $\mathrm{OL}$ & $1.03 \pm 0.06$ & $0.99 \pm 0.05$ & 11.60 & 102 & 0.001 & NO \\
\hline $\mathrm{OW}$ & $1 \pm 0.05$ & $0.98 \pm 0.05$ & 4.33 & 102 & 0.040 & NO \\
\hline IOW & $0.16 \pm 0.05$ & $0.16 \pm 0.03$ & 0.39 & 102 & 0.535 & NO \\
\hline LCR & $1.29 \pm 0.05$ & $1.29 \pm 0.06$ & 0.12 & 102 & 0.730 & NO \\
\hline WN & $0.53 \pm 0.03$ & $0.51 \pm 0.04$ & 13.06 & 102 & $<0.001$ & NO \\
\hline ML & $3.29 \pm 0.09$ & $3.21 \pm 0.11$ & 17.29 & 102 & $<0.001$ & YES \\
\hline MANOVA & & & 8.605 & 10.91 & $<0.001$ & - \\
\hline
\end{tabular}

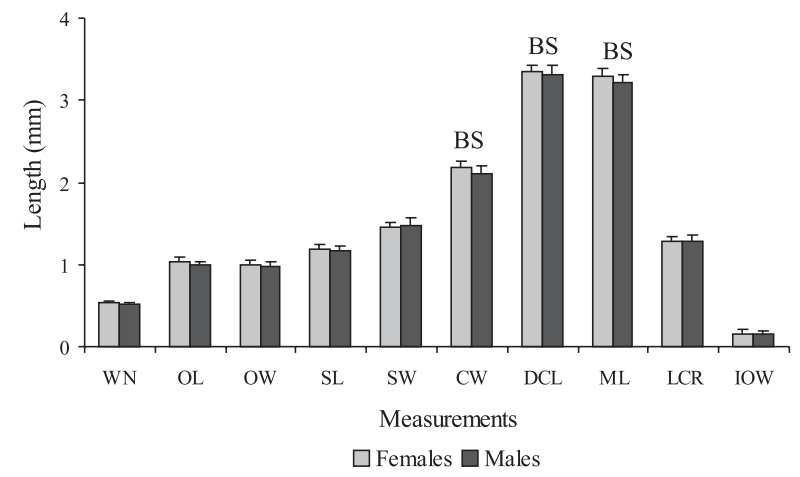

Fig. 2. Length ( $\mathrm{mm}$; Mean \pm Standard Error) of the ten measurements presented in Fig. 1 for males and females at hatching (BS, variables used in the best subset).

\section{DISCUSSION}

The temperature of incubation not only determines sex of embryos but also influences incubation period (WhiteheAd et al., 1990; PÁEZ \& Bock, 1998; PiÑa et al., 2003), pigmentation (DEEMING \& FERGUSON, 1989), and postnatal growth rate (WHITEHEAD et al., 1990). The interaction between these variables has not yet been clarified. For these reasons, in the present study it was not possible to separate the influence of the temperature of incubation from gender on the cranial shape of hatchlings. In addition, clutch-effect, which can also affect cranial morphometrics (L. M. Verdade, unpublished data), were not evaluated in the present study. Therefore, the patterns found here should not be extrapolated to other field studies. However, the present results suggest that there is indeed cranial sexual dimorphism in crocodilian hatchlings and not only in adults.

In general, adult male reptiles present wider and larger head than females (SMITH et al., 1997) which can be related to sexual selection (ANDERSON \& ViTT, 1990; COOPER \& ViTT, 1993). The same pattern has also been found for crocodiles (Hall \& Portier, 1994), and caiman (Verdade, 2003). However, sexual selection is not likely to be so relevant for young as it is for sexually mature individuals (GouLD \&
Gould, 1989; Anderson, 1994). Therefore, the opposite pattern found in the present study - females with larger and wider head - must be related to other selective pressures or biological constraints like for instance niche divergence.

Adult broad-snouted caiman present sexual dimorphism in the upper region of the cranium and not in the mandible, which is the part of the head exposed when animals rest at the water surface (VERDADE, 2000). Considering that crocodilians are predominantly visual animals (BELLAIRS, 1971) there seems to be some social behavioral components in this evolutionary pattern (LANG, 1987). In the present work, hatchlings presented sexual dimorphism in their mandible length (longer in females). This suggests that males and females possibly experience different ontogenetic processes since their embryogenesis.

In adults, most of the variation between sexes is due to size differences of certain regions of the head (VERDADE, 2003). The rate of correct classification reached by the QDF (71.4\%) of the best subset of measurements (DCL, CW, and ML) in the present study is relatively high compared with cloacal sexing of hatchling crocodilians $(57.5$ to $87 \%$ in Crocodylus porosus from 40 to $120 \mathrm{~cm}$ SVL; because of high misclassification they did not evaluate smaller hatchlings: WeBB \& MeSSEL, 1978; 10\% in six month-old alligators: JoAnEn \& MCNEAse, 1978). Although the discrimination rate of this study is not applicable for some management purposes, this information might be useful for zoological garden husbandry and propagation programs where sacrificing animals are usually not justifiable. In order to better evaluate the efficiency of the use of morphometric techniques in sex discrimination of crocodilian hatchlings, future studies should consider using experimental approach including environmental variables such as incubation temperature and humidity, ontogeny, and clutch of origin in order to isolate gender from other variables. These variables can affect not only sex but also growth rate and development of young crocodilians.

\section{CONCLUSIONS}

Based on the results of the present study, we state the following conclusions: 
1) Broad-snouted caiman hatchlings present sexual dimorphism in their cranium;

2) Broad-snouted caiman male hatchlings present smaller cranium than females, contrary to adults;

3) It is possible to discriminate sex in broad-snouted caiman hatchlings by their cranial shape with an efficiency of about $70 \%$.

4) The best variables for discriminating gender are DCL, CW and ML.

Acknowledgments. This study was supported by Proyecto Yacaré, Yacarés Santafesinos (MUPCN) and Fundação de Amparo à Pesquisa do Estado de São Paulo - FAPESP (Proc. No. 00/ 01495-3). We would like to thank other members of Proyecto Yacaré: P. Amavet, P. Donayo, N. Frutos, A. Imhof, and M. Medina for their help with the hatchlings. The authors thanks Jorge González for the drawings.

\section{REFERENCES}

Allsteadt, J. \& Lang, J. W. 1995. Sexual dimorphism in the genital morphology of young American alligators, Alligator mississippiensis. Herpetologica 51(3):314-325.

Anderson, M. 1994. Sexual Selection. Princeton, Princeton University. 599p.

Anderson, M. \& VitT, L. J. 1990. Sexual selection versus alternative causes of sexual dimorphisms in teiid lizards. Oecologia 84(2): $145-157$

Andrews, R.; Mathies, T. \& Warner, D. 2000. Effect of incubation temperature on morphology, growth, and survival of juvenile Sceloporus undulatus. Herpetological Monographs 14(1):420-431.

Bellairs, A. D'A. 1971. The senses of crocodilians. Proceedings of the First Working Meeting of the Crocodile Specialist Group 1:181-189. (IUCN Special Publications).

Brazaitis, P. 1969. The determination of sex in living crocodilians British Journal of Herpetology 4(3):54-58

Burger, J. 1991. Effects of incubation temperature on behavior of hatchling pine snakes: implications for reptilian distribution. Behavioral Ecology and Sociobiology 28(4):297-303.

Chabreck, R. 1963. Methods of capturing, marking and sexing alligators. Proceedings of the Annual Conference Southeastern Association of Game and Fish Commission 17:47-50.

Cooper, W. E. \& VitT, L. J. 1993. Female mate choice of large male broad-headed skinks. Animal Behaviour 45(4):683-693.

Deeming, D. C. \& Ferguson, M. W. J. 1989. The mechanism of temperature-dependent sex determination in crocodilians: a hypothesis. American Zoologist 29(3):973-986.

Doughty, P. \& Shine, R. 1995. Life in two dimensions: Natural history of the southern leaf-tailed gecko, Phyllurus platurus. Herpetologica 51(2):193-201.

Fitch, H. 1981. Sexual size differences in reptiles. The University of Kansas Museum of Natural History, Miscellaneous Publication, 70:1-72.

Garnet, S. \& Murray, M. 1986. Parameters affecting the growth of the estuarine crocodile, Crocodylus porosus, in captivity. Australian Journal of Zoology 34(2):211-223.

Gould, J. L. \& Gould, C. G. 1989. Sexual selection: mate choice and courtship in nature. New York, Scientific American Library. 277p.

GRIfFith, H. 1991. Heterochrony and evolution of sexual dimorphism in the fasciatus group of the scincid genus Eumeces. Journal of Herpetology 25(1):24-30.

Hall, P. M. \& Portier, K. M. 1994. Cranial morphometry of New Guinea crocodiles (Crocodylus novaeguineae): ontogenetic variation in relative growth of the skull and an assessment of its utility as a predictor of the sex and size of individuals. Herpetological Monographs (8):203-225.

Hedrick, A. V. \& Temeles, E. J. 1989. The evolution of sexual dimorphism in animals: hypoteses and tests. Trends in Ecology and Evolution 4(55):136-138.

InfoStat. 1998. InfoStat, Software Estadístico. Grupo InfoStat, Universidad Nacional de Córdoba.

Iordansky, N. N. 1973. The skull of the Crocodylia. In: Gans, C. \& Parsons, T. S. eds. Biology of the Reptilia. Vol. 4. Morphology D. London, Academic Press. p.201-262.

JANZEN, F. J. 1995. Experimental evidence for the evolutionary significance of temperature sex determination. Evolution 49:864-873.

JoAnen, T. \& McNease, L. 1978. The cloacal sexing method for immature alligators. Proceedings from the Annual Conference of the Southeastern Association of Fish and Wildlife Agencies 32:179-181.

LANG, J. W. 1987. Crocodilians behaviour: implication for management. In: WebB, G. J. W.; Manolis, S. C. \& Whitehead, P. J. eds. Wildlife management: crocodiles and alligators. Chipping Norton, Surrey Beatty \& Sons/Conservation Commission of the Northern Territory. p.273-294.

LANG, J. W. \& Andrews, H. V. 1994. Temperature-dependent sex determination in crocodilians. Journal of Experimental Zoology 270:28-44

Magnusson, W. E.; Lima, A. P.; Hero, J. M.; Sanaiotil, T. M. \& Yamakoshi, M. 1990. Paleosuchus trigonatus nests: sources of heat and embryo sex ratios. Journal of Herpetology 24(4):397-400.

Minitab. 2000. Minitab for Windows Release 13. State College, Minitab, Inc. 964p.

PÁez, V. P. \& Bоск, B. C. 1998. Temperature effect on incubation period in the yellow-spotted river turtle, Podocnemis unifilis, in the Colombian Amazon. Chelonian Conservation and Biology 3(1):31-36.

Piña, C. I.; Larriera, A. \& Cabrera, M. 2003. Effect of incubation temperature on incubation period, sex ratio, hatching success, and survivorship in Caiman latirostris (Crocodylia, Alligatoridae). Journal of Herpetology 37(1):199-202.

Rhen, T. \& LANG, J. W. 1999. Temperature during embryonic and juvenile development influences growth in hatchling snapping turtles, Chelydra serpentina. Journal of Thermal Biology 24(1):33-41.

Shine, R. 1989. Ecological causes for the evolution of sexual dimorphism: a review of the evidence. The Quarterly Review of Biology 64(4):419-461.

Shine, R. \& Harlow, P. S. 1996. Maternal manipulation of offspring phenotypes via nest-site selection in an oviparous lizard. Ecology 78:2559-2568.

Smith, G.; Lemos-Espinal, J. \& Ballinger, R. 1997. Sexual dimorphism in two species of Knob-scaled lizards (Genus Xenosaurus) from Mexico. Herpetologica 53(2):200-205.

SoKal, R. R. \& Rohlf, F. J. 1995. Biometry: the principles and practice of statistics in biological research. New York, W. H. Freeman and Company. 887p.

Verdade, L. M. 2000. Regression equations between body and head measurements in the broad-snouted caiman (Caiman latirostris). Revista Brasileira de Biologia 60(3):469-482. 2001. Allometry of reproduction in broad-snouted caiman (Caiman latirostris). Brazilian Journal of Biology 61(3): 171-175.

2003. Cranial sexual dimorphism in captive adult broadsnouted caiman (Caiman latirostris). Amphibia-Reptilia 24(1):92-99.

Webb, G. \& Messel, H. 1978. Morphometrics analysis of Crocodylus porosus from the north coast of Arnhem Land, northern Australia. Australian Journal of Zoology 26(1):1-27.

Whitehead, P. J., Webb, G. J. W. \& Seymour, P. J. 1990. Effect of incubation temperature on development of Crocodylus johnstoni embryos. Physiological Zoology 63(5):949-964. 